\title{
NITRATE LEACHING FROM A MOUNTAIN FOREST ECOSYSTEM WITH GLEYSOLS SUBJECTED TO EXPERIMENTALLY INCREASED N DEPOSITION
}

\author{
PATRICK SCHLEPPI*, FRANK HAGEDORN and ISABELLE PROVIDOLI \\ Swiss Federal Institute for Forest, Snow and Landscape Research (WSL), CH-8903 Birmensdorf, \\ Switzerland \\ (*author for correspondence, e-mail: schleppi@wsl.ch; phone: +41 173924 22; \\ fax: +41 17392488$)$
}

(Received 20 August 2002; accepted 10 May 2003)

\begin{abstract}
Nitrate leaching was measured over seven years of nitrogen $(\mathrm{N})$ addition in a pairedcatchment experiment in Alptal, central Switzerland (altitude: $1200 \mathrm{~m}$, bulk N deposition: $12 \mathrm{~kg}$ $\left.\mathrm{ha}^{-1} \mathrm{a}^{-1}\right)$. Two forested catchments $\left(1500 \mathrm{~m}^{2}\right.$ each) dominated by Picea abies $)$ were delimited by trenches in the Gleysols. $\mathrm{NH}_{4} \mathrm{NO}_{3}$ was added to one of the catchments using sprinklers. During the first year, the $\mathrm{N}$ addition was labelled with ${ }^{15} \mathrm{~N}$. Additionally, soil $\mathrm{N}$ transformations were studied in replicated plots. Pre-treatment $\mathrm{NO}_{3}^{-}-\mathrm{N}$ leaching was $4 \mathrm{~kg} \mathrm{ha}^{-1} \mathrm{a}^{-1}$ from both catchments, and remained between 2.5 and $4.8 \mathrm{~kg} \mathrm{ha}^{-1} \mathrm{a}^{-1}$ in the control catchment. The first year of treatment induced an additional leaching of $3.1 \mathrm{~kg} \mathrm{ha}^{-1}$, almost $90 \%$ of which was labelled with ${ }^{15} \mathrm{~N}$, indicating that it did not cycle through the large $\mathrm{N}$ pools of the ecosystem (soil organic matter and plants). These losses partly correspond to $\mathrm{NO}_{3}^{-}$from precipitation bypassing the soil due to preferential flow. During rain or snowmelt events, $\mathrm{NO}_{3}^{-}$concentration peaks as the water table is rising, indicating flushing from the soil. Nitrification occurs temporarily along the water flow paths in the soil and can be the source of $\mathrm{NO}_{3}^{-}$flushing. Its isotopic signature however, shows that this release mainly affects recently applied $\mathrm{N}$, stored only between runoff events or up to a few weeks. At first, the ecosystem retained $90 \%$ of the added $\mathrm{N}\left(2 / 3\right.$ in the soil), but $\mathrm{NO}_{3}^{-}$losses increased from 10 to $30 \%$ within $7 \mathrm{yr}$, indicating that the ecosystem became progressively $\mathrm{N}$ saturated.
\end{abstract}

Keywords: forest ecosystem, Gleysols, nitrate leaching, nitrogen deposition, paired-catchment experiment

\section{Introduction}

Deposition of inorganic nitrogen $(\mathrm{N})$ to terrestrial ecosystems has increased over the past decades due to emissions associated with human activities. Increased inputs of ammonium $\left(\mathrm{NH}_{4}^{+}\right)$and nitrate $\left(\mathrm{NO}_{3}^{-}\right)$can induce eutrophication of previously N-limited systems, including forests, and finally cause their 'nitrogen saturation' (Ågren and Bosatta, 1988; Aber et al., 1989). According to these authors, increases in plant $\mathrm{N}$ uptake and $\mathrm{N}$ mineralisation occur before saturation is reached. Then, at saturation, there is a sharp increase in nitrification. Nitrate leaching, finally, increases as the $\mathrm{N}$ saturation continues. Nitrate leaching is thus 
usually regarded as the main symptom of $\mathrm{N}$ saturation in forests (Gundersen et al., 1998).

As part of the European research project NITREX (Wright and Rasmussen, 1998; Emmett et al., 1998), we studied the effects of increased N deposition on a mountain forest in Alptal, Switzerland (Schleppi et al., 1998). Nitrogen was added underneath the tree crowns both in a paired-catchment experiment and in a replicated plot design. We found that under ambient conditions as well as with increased $\mathrm{N}$ deposition, $\mathrm{NO}_{3}^{-}$leaching from the Gleysols of this site did not fit into the concept of $\mathrm{N}$ saturation by Aber et al. (1989). Specifically, $\mathrm{NO}_{3}^{-}$leaching occurred even if the trees were still slightly deficient in $\mathrm{N}(1.1 \% \mathrm{~N}$ in needles) and if no effects of the $\mathrm{N}$ addition were observed on the vegetation (Schleppi et al., 1999b). Further, neither the inorganic $\mathrm{N}$ pools in the soil (extractable $\mathrm{NO}_{3}^{-}$and $\mathrm{NH}_{4}^{+}$) nor the net nitrification were affected by two years of $\mathrm{N}$ addition, but $\mathrm{NO}_{3}^{-}$ leaching clearly increased (Hagedorn et al., 2001).

In the model of $\mathrm{N}$ saturation by Stoddard (1994), some of the deposited $\mathrm{NO}_{3}^{-}$ may bypass the ecosystem during winter and spring before any $\mathrm{N}$ saturation. Concentrations measured at Alptal during the dormant season would fit to this 'stage 0 '. Nitrate leaching, however, also happens regularly during the summer, which would point to advanced (stage 2) saturation. It is therefore not possible to classify our site on Stoddard's scale.

In most cases, $\mathrm{NO}_{3}^{-}$leaching from forest ecosystems is studied on upland soils without waterlogging. Leaching itself is often calculated from concentrations in the soil solution collected below the rooting depth. Results from such experiments should not be extrapolated to the relatively impermeable Gleysols of our site. There, dye-tracer experiments showed a fast, preferential flow of infiltrating precipitation towards drainage trenches (Feyen et al., 1999), and water flow paths with increased $\mathrm{NO}_{3}^{-}$concentrations could indeed be detected by microsuction cups (Hagedorn et al., 1999). We therefore proposed that $\mathrm{NO}_{3}^{-}$in the runoff from this forest largely corresponds to $\mathrm{NO}_{3}^{-}$from rain or snowmelt bypassing the soil matrix. This hypothesis is supported by the high proportion of ${ }^{15} \mathrm{~N}$-labelled $\mathrm{NO}_{3}^{-}$leached from the treated catchment, indicating that it comes mainly from the applied $\mathrm{N}$ and not from an increased net mineralization of (unlabelled) soil N (Schleppi et al., 1999a).

An end-member mixing analysis (EMMA) also showed that, at peak discharge, more than half of the runoff water in the experimental catchments came directly from precipitation (Hagedorn et al., 2001). For a whole rainfall event, however, this direct contribution appeared to be only approximately 20\%. The EMMA model was further able to predict $\mathrm{NO}_{3}^{-}$leaching with a high coefficient of determination, but these predictions were systematically too low, reaching approximately $60 \%$ of the measured values. Even when the model clearly indicates some direct $\mathrm{NO}_{3}^{-}$ leaching due to a lack of interaction with the soil ('new' $\mathrm{N}$ ), the analysis suggests a considerable contribution of pre-event ('old') N. This contradicts the minimal proportion of unlabelled $\mathrm{N}$ in the additional leaching induced by the treatment. 
In this paper, we present both short- and long-term patterns of $\mathrm{NO}_{3}^{-}$leaching with the aim of reconciling these previous findings on the relative contributions of 'new' and 'old' $\mathrm{N}$.

\section{Material and Methods}

\subsection{Site DESCRIPTION}

The Alptal valley is located in central Switzerland. The research site is at an altitude of $1200 \mathrm{~m}$ and has a cool, wet climate $\left(6{ }^{\circ} \mathrm{C}\right.$ mean temperature and 2300 $\mathrm{mm}$ precipitation per year, of which $800 \mathrm{~mm}$ is as snow). Atmospheric $\mathrm{NO}_{3}^{-}$and $\mathrm{NH}_{4}^{+}$deposition is moderate: 12 and $17 \mathrm{~kg} \mathrm{~N} \mathrm{ha}^{-1} \mathrm{a}^{-1}$ in bulk and throughfall respectively (Schleppi et al., 1998). Umbric Gleysols occur atop a Flysch substratum (calcareous sandstones with clay-rich schists, a typical formation along the northern edge of the Alps). The slope is about $20 \%$ with a west aspect. Depending on the microtopography, the soil bears different humus types: mor (raw humus) on the mounds and anmoor (muck humus) in the depressions, where the water table is high and reducing conditions common.

The trees are predominantly Norway spruce (Picea abies), with 15\% silver fir (Abies alba), and mainly grow on the mounds. The stand is naturally regenerated, with trees up to $250 \mathrm{yr}$ old. With a leaf area index of 3.8, the density of the canopy is low; the basal area is $41 \mathrm{~m}^{2} \mathrm{ha}^{-1}$ for $430 \mathrm{stems} \mathrm{ha} \mathrm{s}^{-1}$ (>10 $\mathrm{cm}$ in diameter). The ground vegetation is well developed; different botanical associations form patches according to humus types and light conditions (Schleppi et al., 1999b).

\subsection{EXPERIMENTAL CATCHMENTS AND N ADDITION}

Two forested catchments, each approximately $1500 \mathrm{~m}^{2}$ in size, were delimited by trenches (Schleppi et al., 1998). The yearly water budgets for each catchment were found to be approximately balanced, and discharge and water chemistry are comparable with the surrounding, natural catchment of the Erlenbach stream (Schleppi et al., 1998). Element budgets of the artificially delimited catchments can thus be calculated from precipitation and runoff samples. The depth of the water table is automatically measured in two piezometers, one on a mound, one in a slight depression on the slope.

Nitrogen (as $\mathrm{NH}_{4} \mathrm{NO}_{3}$ ) was added to rainwater during precipitation events and applied by sprinklers to one of the catchments. This simulated an increased deposition of $25 \mathrm{~kg} \mathrm{~N} \mathrm{ha}^{-1} \mathrm{a}^{-1}$ to the ground vegetation and the soil. The water used as a vector for the $\mathrm{N}$ addition corresponded to a supplementary precipitation of approximately $110 \mathrm{~mm}$ per year. During the winter, the automatic irrigation was replaced by the occasional application of a concentrated $\mathrm{NH}_{4} \mathrm{NO}_{3}$ solution on the snow with a backpack-sprayer. The seasonality of the ambient deposition rates was thereby approximately mimicked. The effects of the treatment were compared 
with a control catchment receiving only unaltered rainwater and with one year of pre-treatment measurements made from both catchments.

\subsection{SAMPLING AND ANALYSES}

Bulk deposition and throughfall samples were collected weekly. In both catchments, water discharge was continuously measured with V-notch weirs. Runoff samples were collected proportionally to the discharge and bulked weekly (Schleppi et al., 1998). Additionally, runoff from several rainfall and snowmelt events was monitored with a high temporal resolution (Hagedorn et al., 2000). Soil solution samples were collected from plots $\left(20 \mathrm{~m}^{2}\right.$ each, 5 replications) located near the catchments and subjected to the same $\mathrm{N}$ treatments. Suction plates were used to sample water at 5 and $10 \mathrm{~cm}$ depth, suction cups for $30 \mathrm{~cm}$ (reduced Bg horizon) (Hagedorn et al., 2000). Anions in water samples were analysed by ion chromatography (Schleppi et al., 1998). Soil cores were taken after 2 and $7 \mathrm{yr}$ on 20 grid points of the treated catchment and analysed for carbon (C) and $\mathrm{N}$ contents with a $\mathrm{C}+\mathrm{N}$ analyser.

\section{4. ${ }^{15} \mathrm{~N}$ LABELLING}

The added $\mathrm{N}$ was labelled with ${ }^{15} \mathrm{NH}_{4}^{15} \mathrm{NO}_{3}$ during the first treatment year (Schleppi et al., 1999a). Water samples, pooled quarterly, were concentrated over exchange resins. Anions and cations were eluted separately and $\mathrm{NO}_{3}^{-}$was reduced to $\mathrm{NH}_{4}^{+}$ with Devarda's alloy. Ammonium was converted to $\mathrm{NH}_{3}$ and captured in fibreglass filters enclosed in teflon membranes (adapted from Downs et al., 1999). The filters were analysed by mass spectrometry.

\section{Results}

\subsection{EVENT-BASED ANALYSES OF $\mathrm{NO}_{3}^{-}$LEACHING}

An initial event-based sampling of runoff water was done in August 1994, during the pre-treatment year and at the end of a wet week $(60 \mathrm{~mm}$ precipitation in the 6 previous days). During the sampled $12 \mathrm{~h}$ rainfall event, $\mathrm{NO}_{3}^{-}$concentrations were highest during the first discharge peak (Figure 1). By the end of the runoff peak, these concentrations had progressively declined to values close to those measured before the rain. During this event, $\mathrm{NO}_{3}^{-}$concentrations in the runoff remained within the range measured in the topsoil solution $\left(\mathrm{NO}_{3}^{-}-\mathrm{N}\right.$ : $0.05-0.7 \mathrm{mg} \mathrm{L}^{-1}$, Hagedorn et al., 2001). They were also similar to concentrations in the rain itself $\left(0.22 \mathrm{mg} \mathrm{L}{ }^{-1} \mathrm{NO}_{3}^{-}-\mathrm{N}\right)$. In the first samples from each catchment, the $\mathrm{NO}_{3}^{-}-\mathrm{N}^{-\mathrm{Cl}^{-}}$ ratios were 0.6 and 1.4, respectively. From the second to the last samples, the ratios declined from 0.5 down to below 0.4 in both catchments. 


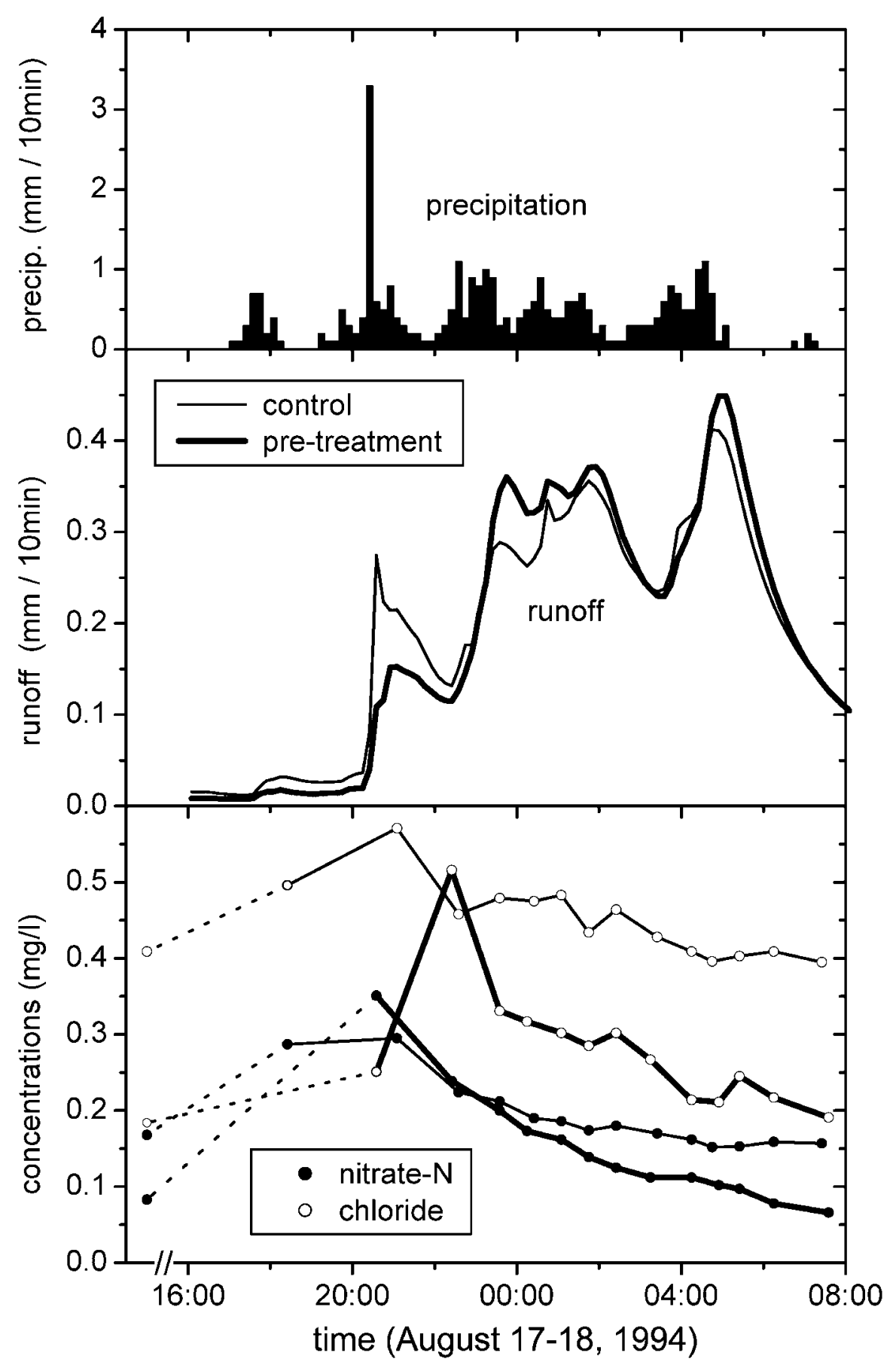

Figure 1. Runoff from the experimental catchments and its concentrations in $\mathrm{NO}_{3}^{-}$and chloride during a summer rainfall event, before the $\mathrm{N}$ addition started. 


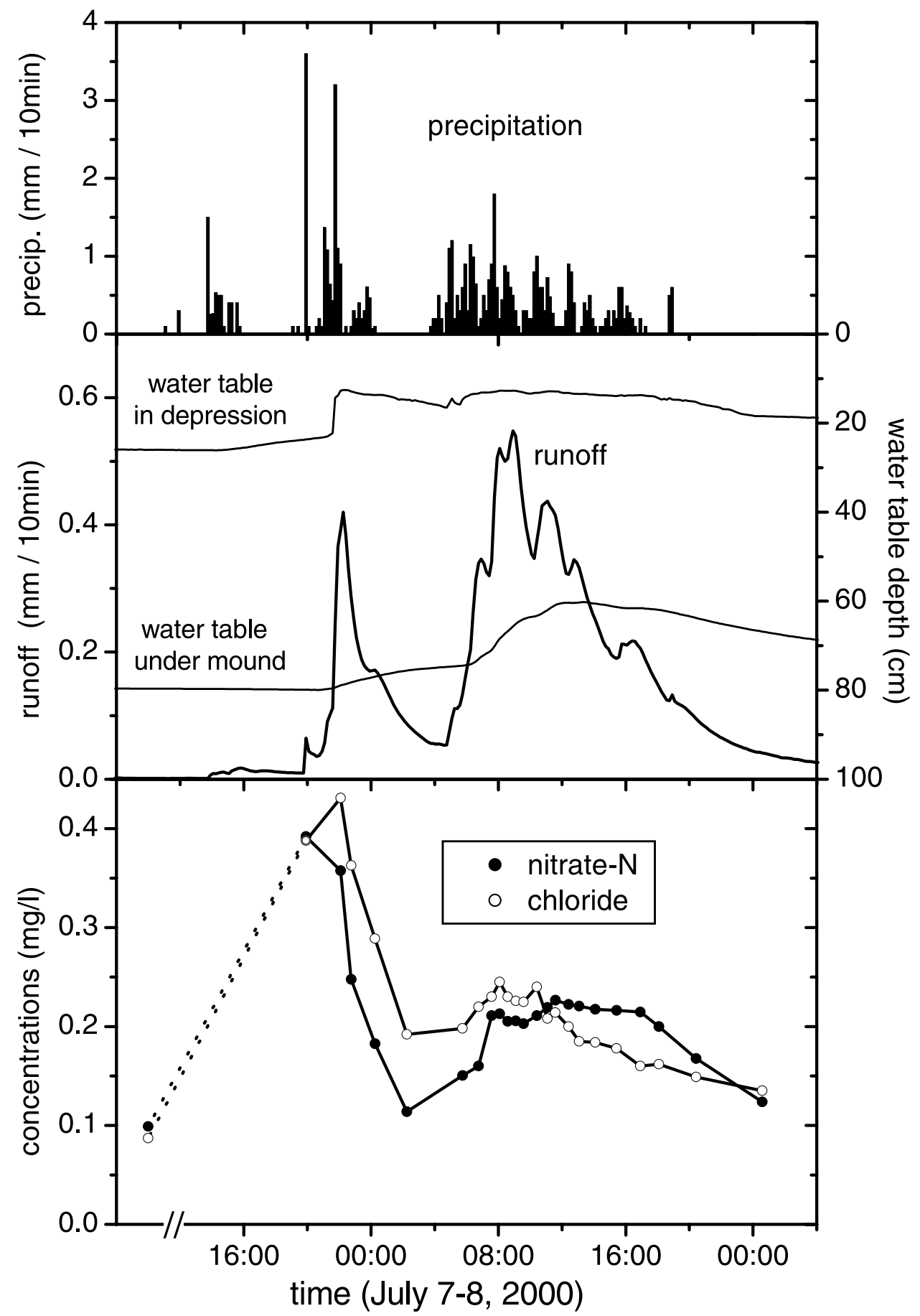

Figure 2. Runoff from the control catchment, its concentrations in $\mathrm{NO}_{3}^{-}$and $\mathrm{Cl}^{-}$, and depth of the water table during a summer rainfall event. 
In samples collected in July 2000 from the first runoff peak of another long rainfall event (Figure 2), $\mathrm{NO}_{3}^{-}$concentrations increased above values measured in the soil solution, or in the precipitation of this event $\left(\mathrm{NO}_{3}^{-}-\mathrm{N}: 0.31 \mathrm{mg} \mathrm{L}^{-1}\right)$. The water table in the depression piezometer also rose sharply during this first runoff peak. During the second part of the event, the water table remained high in the depression, and slowly increased in the mound piezometer. At the same time, a broad $\mathrm{NO}_{3}^{-}$peak was measured in the runoff. During the first discharge peak, the ratio $\mathrm{NO}_{3}^{-}-\mathrm{N} / \mathrm{Cl}^{-}$dropped from 1 to 0.6 . Then, during the second peak, it increased up to 1.2 , before decreasing again in the last three samples down to 0.9 .

The first two days of the main snowmelt period were also sampled in April 1995, before the $\mathrm{N}$ treatment began (Figure 3). These samples showed a general decrease in $\mathrm{NO}_{3}^{-}$concentrations, except for a short peak on the second day. In each catchment, this $\mathrm{NO}_{3}^{-}$peak corresponded to the maximum runoff, and also approximately to the maximum water table levels.

The analysis of one rainfall event in July 1998, during the $\mathrm{N}$ addition, has previously been presented in Hagedorn et al. (2001). There was a $\mathrm{NO}_{3}^{-}$peak at the beginning of the event, and $\mathrm{NO}_{3}^{-}$concentrations were elevated in the runoff of the treated catchment throughout the event.

Runoff water was further sampled in April 1999 during the 6th and 7th days of a long snowmelt period (Figure 4). Compared to the event sampled in April 1995, the $\mathrm{NO}_{3}^{-}$and $\mathrm{Cl}^{-}$concentrations were low and stable in the runoff from the control catchment. In the N-treated catchment, $\mathrm{Cl}^{-}$was also low, but $\mathrm{NO}_{3}^{-}$concentrations were elevated during the whole event.

\subsection{WEEKLY ANALYSES OF $\mathrm{NO}_{3}^{-}$LEACHING}

Over the seven years of weekly runoff analyses, low $\mathrm{NO}_{3}^{-}$concentrations were usually measured in discharge-proportional samples collected during the summer. Higher concentrations were observed when the soil was relatively dry, like in autumn 1995, or during snowmelt, as in winter 1996 (Figure 5). During snowmelt, high concentrations are sometimes coupled to high discharges, leading to considerable $\mathrm{NO}_{3}^{-}$fluxes. Over $7 \mathrm{yr}, 45 \%$ of the losses from the control catchment occurred during three months of the year, between March and May. Based on these observations, a multiple regression analysis was calculated to explain $\mathrm{NO}_{3}^{-}$concentrations in weekly runoff samples from the control catchment. The concentration data were first transformed to their logarithms in order to obtain a normal distribution of the residues. Independent variables were: the discharge (as logarithm), the season (as sine and cosine functions with a one year period), the variations of the water table (as the sum of hourly increases), and the bulk $\mathrm{N}$ deposition during the week (after subtracting the proportion of snow). The regression model had a coefficient of determination $r^{2}=0.43$ for the control catchment and each factor was highly significant $(p<0.001)$, also in a stepwise model definition. The effect of the discharge was evident but relatively weak: $\mathrm{NO}_{3}^{-}$concentrations changed by a factor 10 


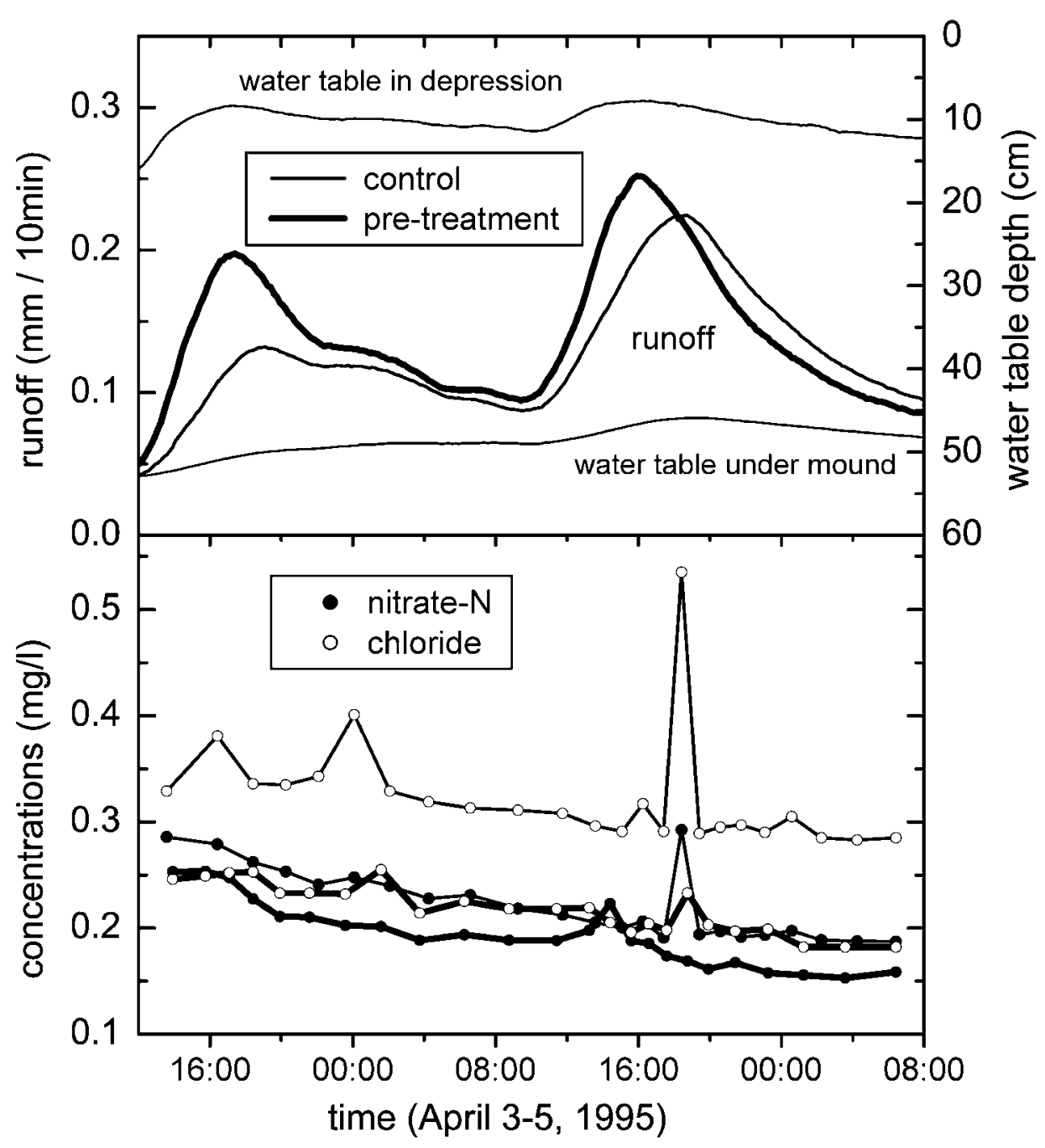

Figure 3. Runoff from the experimental catchments, its concentrations in $\mathrm{NO}_{3}^{-}$and $\mathrm{Cl}^{-}$, and depth of the water table during two days at the beginning of a snowmelt period.

while the discharge changed by more than 4 orders of magnitude. The maximum of the seasonality curve was in April, 2.5 times as high as the minimum in October. Nitrate concentrations further increased by $2 \%$ for each $\mathrm{cm}$ that the water table rose during the week. In the treated catchment, the effect of the discharge remained, but the seasonality was damped, with a ratio of 1.6 between spring and autumn concentrations. With the addition of $\mathrm{N}$, the effect of the water table fluctuations was no longer significant. 


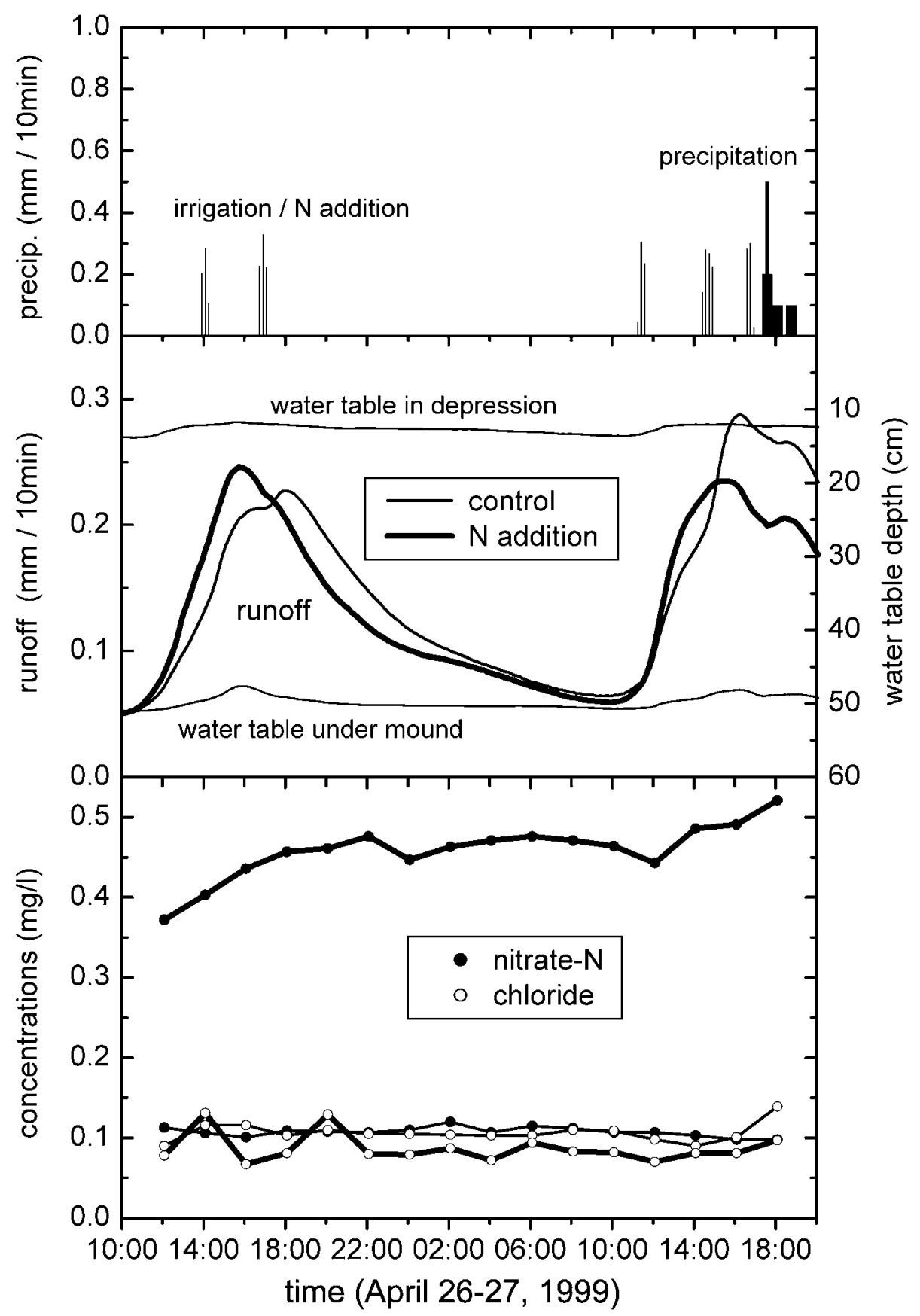

Figure 4. Runoff from the experimental catchments, its concentrations in $\mathrm{NO}_{3}^{-}$and $\mathrm{Cl}^{-}$, and depth of the water table during a longer snowmelt period. In the treated catchment, the water delivered by the irrigation system contained $17 \mathrm{ml} \mathrm{L}^{-1}$ of $\mathrm{N}$. 


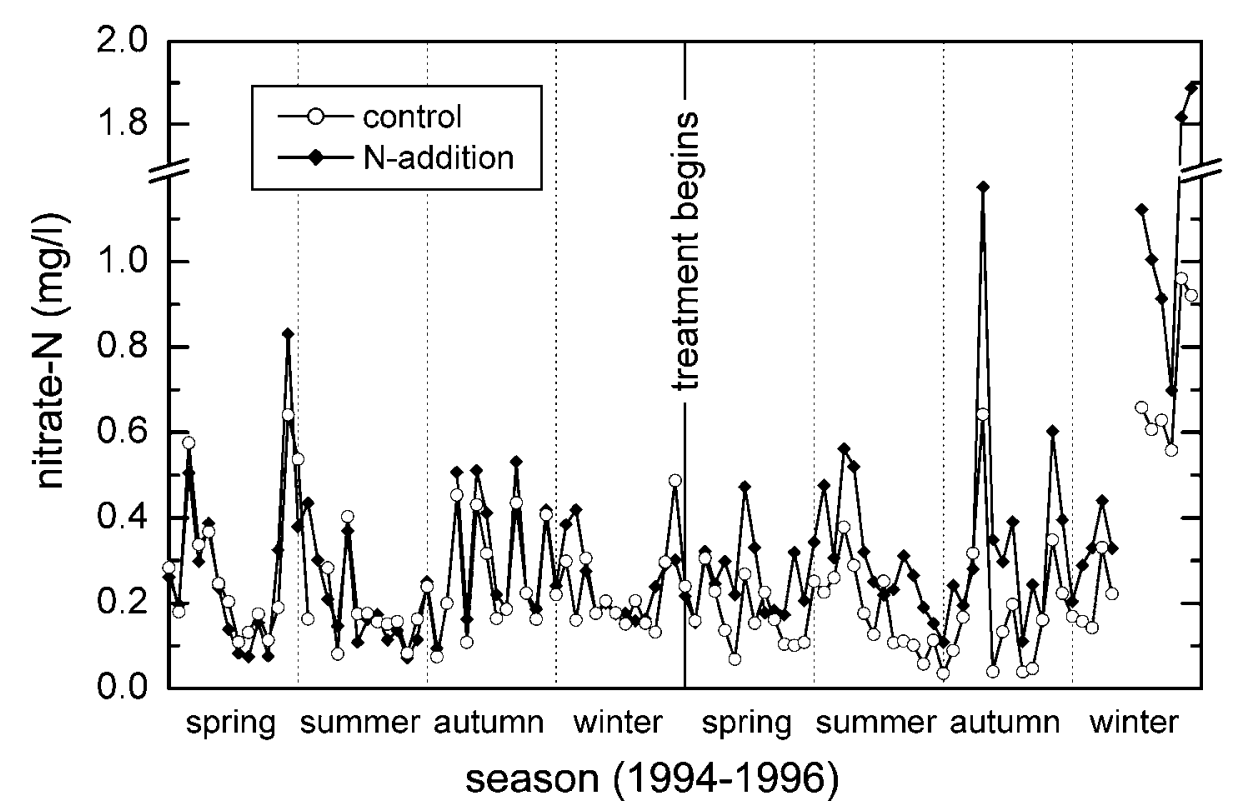

Figure 5. Nitrate concentrations in discharge-proportional runoff samples from the experimental catchments, with the addition of $\mathrm{N}$ beginning in the treated catchment after one year of pre-treatment measurements.

The weekly discharge-proportional samples from both catchments were very similar during the pre-treatment year (Figure 5). Within weeks of beginning the $\mathrm{N}$ application, the $\mathrm{NO}_{3}^{-}$concentrations in runoff doubled in the treated catchment compared to the control catchment. Thereby, the shape of the concentration curve remained almost the same (correlation: $r=0.73, p<0.001$ ), only its magnitude was increased.

\subsection{LONG-TERM TRENDS}

Nitrate-N leaching from the control catchment varied from year to year between 2.5 and $4.8 \mathrm{~kg} \mathrm{ha}^{-1}$ (Figure 6). It was significantly correlated with the yearly bulk $\mathrm{N}$ deposition $\left(r^{2}=0.63, p=0.02\right)$.

In the first treatment year, $\mathrm{NO}_{3}^{-}$leaching was $3.1 \mathrm{~kg} \mathrm{~N}$ higher in the treated catchment than in the control, corresponding to $11 \%$ of the $\mathrm{N}$ addition. Out of these $3.1 \mathrm{~kg}, 2.8 \pm 0.3$ were labelled $\mathrm{N}$. In the following years, the difference between the catchments increased up to $7 \mathrm{~kg} \mathrm{~N}$, or $30 \%$ of the addition. The ${ }^{15} \mathrm{~N}$ signal in runoff $\mathrm{NO}_{3}^{-}$, however, disappeared within three months from the end of the labelling. The difference between total ${ }^{15} \mathrm{~N}$ in lyophilised samples and ${ }^{15} \mathrm{NO}_{3}^{-}$ did not indicate any labelled dissolved organic $\mathrm{N}$, nor was any ${ }^{15} \mathrm{~N}$ signal detected in throughfall after labelling. 


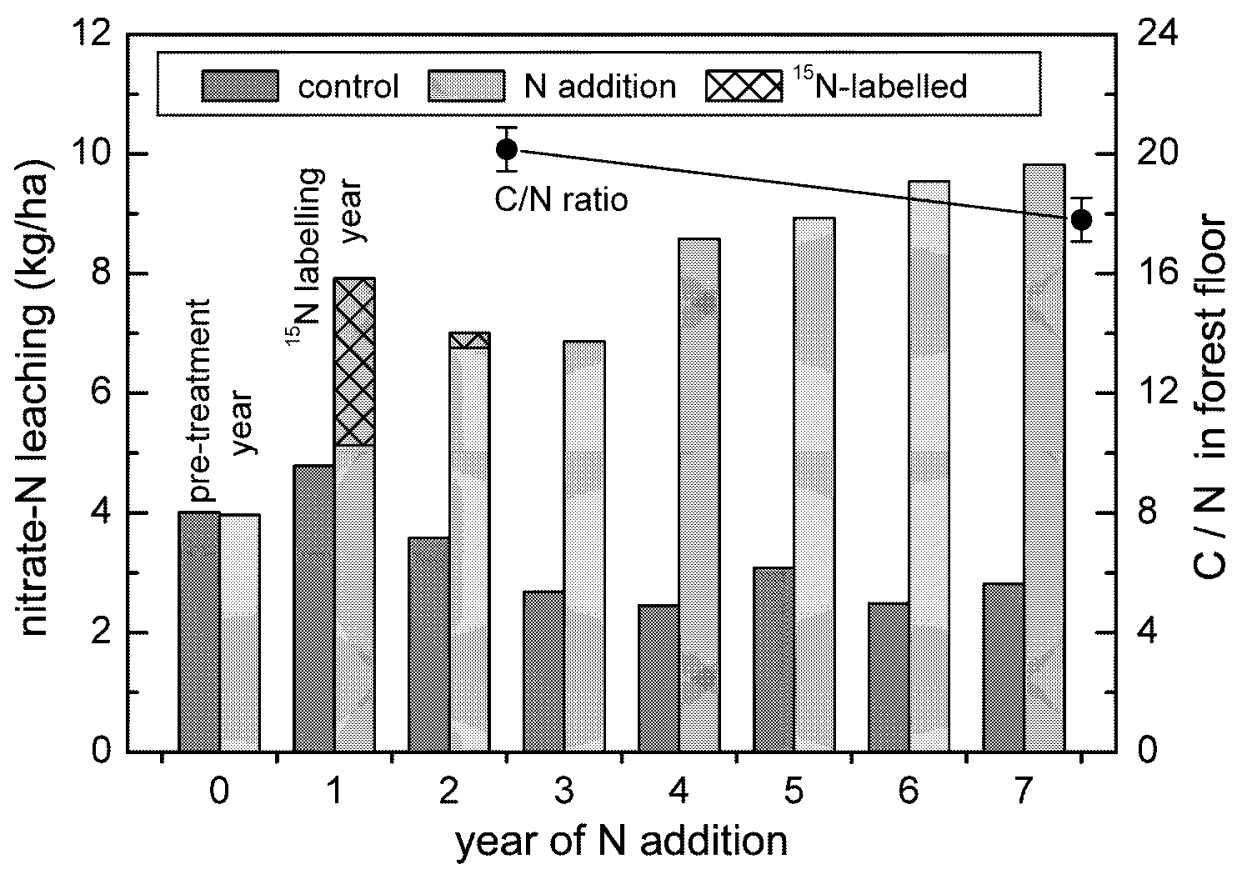

Figure 6. Yearly $\mathrm{NO}_{3}^{-}$leaching from the forested experimental catchments during a pre-treatment year $(0$ davidson $=1994-1995)$ followed by seven years of $\mathrm{N}$ addition (at $25 \mathrm{~kg} \mathrm{ha}^{-1} \mathrm{a}^{-1}$, with ${ }^{15} \mathrm{~N}$ labelling in year 1). $\mathrm{C} / \mathrm{N}$ mass ratios $( \pm$ std. error) in the forest floor of the treated catchment after 2 and $7 \mathrm{yr}$ of $\mathrm{N}$ addition.

Between 1997 and 2002, the $\mathrm{C} / \mathrm{N}$ ratio of the forest floor decreased significantly ( $p=0.02$ ) from 20.2 to $17.8 \%$. If the $\mathrm{C}$ content is assumed constant, this corresponds to an accumulation of $23 \pm 10 \mathrm{~kg} \mathrm{~N} \mathrm{ha}^{-1} \mathrm{a}^{-1}$.

\section{Discussion}

In winter, the occasional application of $\mathrm{NH}_{4} \mathrm{NO}_{3}$ to the snow appears to have a sustained effect on $\mathrm{NO}_{3}^{-}$concentrations in runoff water. During runoff events, the single $\mathrm{N}$ additions by the sprinklers had no distinguishable effect on the concentration curves of $\mathrm{NO}_{3}^{-}$in runoff. Finally, the treatment clearly increased weekly $\mathrm{NO}_{3}^{-}$concentrations, but did not change the shape of this time-series compared to the control. These observations show that the applications were frequent enough to simulate wet $\mathrm{N}$ deposition, even on our site with rapid runoff. This is important since the same amount of nutrient can induce different effects depending on the rate and frequency of application (Persson, 1981), which can then alter the partitioning between plant species, soil, soil microorganisms, and leaching (Johnson, 1992). Our treatment by sprinklers does not allow for a foliar uptake by the trees. This 
process, however, was shown to be small in the case of wet deposition (Wilson and Tiley, 1998).

Using natural abundances of ${ }^{15} \mathrm{~N}$ and ${ }^{18} \mathrm{O}$ from riverine nitrate, Mayer et al. (2002) established that, in large forested catchments, $\mathrm{NO}_{3}^{-}$leaching was mainly from nitrification, with only a small possibility of a direct contribution from atmospheric deposition. Our ${ }^{15} \mathrm{~N}$ labelling gives opposite results, with $90 \%$ of the additional leaching being labelled. If there are interactions between added $\mathrm{N}$ and pre-existing ecosystem pools, they must be limited to small $\mathrm{N}$ pools and to a relatively short time span (since the ${ }^{15} \mathrm{~N}$ signal disappeared from the runoff within three months).

Event-based analyses, including the already published end-member mixing analysis (Hagedorn et al., 2001), show a different pattern. Nitrate peaks usually correspond to a rising water table. This indicates flushing from those soil layers, which become saturated with water (Creed and Band, 1998). Because the water table always rises first in the depressions and only later under the mounds, $\mathrm{NO}_{3}^{-}$flushing can also occur as successive $\mathrm{NO}_{3}^{-}$peaks during a hydrological event, like in July 2000. This effect is similar to the 'variable source area dynamics' described by Creed and Band (1998). Nitrate peaks observed during the early snowmelt in April 1995 also corresponded to the water table reaching a previously unsaturated soil layer. The highest $\mathrm{NO}_{3}^{-}$peak, however, occurred simultaneously with a $\mathrm{Cl}^{-}$peak. These high concentrations indicate hydrological causes (which affect both anions), without a contribution of net nitrification (which would increase the $\mathrm{NO}_{3}^{-} / \mathrm{Cl}^{-}$ratio). During the snowmelt sampled in April 1999, concentrations were consistently low in the control catchment. Concentrations declining during the early snowmelt and staying low through the later snowmelt phase are best explained by the ionic fractionation within the melting snowpack (Waldner et al., 2000). The higher concentrations observed in the control catchment in April 1995 can be explained by the same mechanisms since its snowmelt is always slightly later than in the treated catchment. The absence of a clear $\mathrm{NO}_{3}^{-}$peak in April 1999 is probably due, as in the rainfall event of August 1994, to previous flushings, which already depleted $\mathrm{NO}_{3}^{-}$from the soil zones reached by the water table.

During some events, like in July $2000, \mathrm{NO}_{3}^{-}$peaks correspond to increased $\mathrm{NO}_{3}^{-} / \mathrm{Cl}^{-}$ratios. In this case, some $\mathrm{NO}_{3}^{-}$appears to be produced by nitrification. Even if no net nitrification was measurable in the bulk soil of this forest site, Hagedorn et al. (1999) showed that some nitrification takes place along the macropores as they drain out between hydrological events. In summary, $\mathrm{NO}_{3}^{-}$is released by the Gleysols at the test catchments by three different mechanisms: (1) $\mathrm{NO}_{3}^{-}$ from precipitation bypassing the soil by fast preferential and sub-surface-flow, (2) flushing of $\mathrm{NO}_{3}^{-}$from previous precipitation events temporarily stored in the soil pores, and (3) flushing of $\mathrm{NO}_{3}^{-}$produced by nitrification (in the macropores of the unsaturated soil). In any case, $\mathrm{NO}_{3}^{-}$flushed as the water table rises is mainly from recently deposited $\mathrm{N}$, as shown by its strong ${ }^{15} \mathrm{~N}$ signal. From the data obtained so far, it is not possible to distinguish between the nitrification of deposited $\mathrm{NH}_{4}^{+}$and 
nitrification occurring after the mineralisation of assimilated $\mathrm{NO}_{3}^{-}$. Because the ${ }^{15} \mathrm{~N}$ signal disappears within three months, these release mechanisms are effective on a limited time-scale only. This explains why event-based and long-term contributions of 'new' vs. 'old' $\mathrm{N}$ appeared to be in contradiction. Likewise, the discrepancy observed in correlations between $\mathrm{NO}_{3}^{-}$and discharge is also a matter of the timescale: mostly positive within a single event, but negative between weekly samples. The effect of flushing, however, can still be observed in the weekly analyses as $\mathrm{NO}_{3}^{-}$concentrations increase with the cumulative movements of the water table during the sampling time. To describe this quantitatively and in more details, it would be necessary to draw a model taking into account the whole dynamics of the water table across the variable zones, which contribute to runoff (mounds vs. depressions).

The observed $\mathrm{NO}_{3}^{-}$leaching mechanisms occur preferentially along water-flow paths in the soil (macropores). Because soil heterogeneity is not considered in the N saturation models by Ågren and Bosatta, (1988) or by Aber et al. (1989), our site cannot be described within these concepts. A further limitation of these models was the fact that $\mathrm{N}$ inputs to the stable soil organic matter are only possible via litterfall. In their newer hypotheses, Aber et al. (1998) also consider direct immobilisation in the soil, which is clearly what happened with the Alptal forest. Even if it was detectable by ${ }^{15} \mathrm{~N}$ analyses, the uptake of deposited $\mathrm{N}$ by the trees was insignificant for their nutritional status (Schleppi et al., 1999b) and thus for the return of $\mathrm{N}$ as litterfall. Foliar leaching did not play a role either as there was no ${ }^{15} \mathrm{~N}$ signal in throughfall after labelling. About $2 / 3$ of the ${ }^{15} \mathrm{~N}$ were recovered in the soil (Schleppi et al., 1999a), and the immobilisation in the forest floor was very important (about $15 \mathrm{~kg} \mathrm{ha}^{-1}$ of labelled $\mathrm{N}$ in litter and forest floor). This immobilisation may be abiotic, especially since reducing conditions are frequent in this soil and could enable the redox cycles recently hypothesised by Davidson $e t$ al. (2003). The decline in the $\mathrm{C} / \mathrm{N}$ ratio measured within five years is strong but still in agreement with the ${ }^{15} \mathrm{~N}$ partitioning. Comparing different sites, Gundersen et al. (1998) and Emmett et al. (1998) showed the importance of the $\mathrm{C} / \mathrm{N}$ ratio in the forest floor for its ability to retain $\mathrm{N}$ deposition. In our experiment, we observed a progressive increase in $\mathrm{NO}_{3}^{-}$leaching within seven years of $\mathrm{N}$ addition. According to its disappearing ${ }^{15} \mathrm{~N}$ signal, this increased leaching is due to a reduced ability to retain further $\mathrm{N}$ inputs rather than to a delayed release of $\mathrm{N}$ accumulated in the previous years. We therefore hypothesise that the declining $\mathrm{C} / \mathrm{N}$ ratio is more and more limiting the ability of the soil to immobilise $\mathrm{N}$ from atmospheric deposition.

\section{Acknowledgments}

This study received financial support from the Swiss Federal Office of Science and Education and from the Swiss National Fund for Scientific Research. The chemical analyses were done at the central laboratory of the Swiss Federal Institute for 
Forest, Snow and Landscape Research (WSL), Birmensdorf (D. Pezzotta). Analyses of ${ }^{15} \mathrm{~N}$ were conducted at the Paul Scherrer Institute (PSI), Villigen (Dr. R. Siegwolf, Dr. M. Saurer). Thanks to Melissa Swartz for the English corrections.

\section{References}

Aber, J. D., Nadelhoffer, K. J., Steudler, P. and Melillo, J.: 1989, 'Nitrogen saturation in northern forest ecosystems', BioScience 39, 378-386.

Aber, J., McDowell, W., Nadelhoffer, K., Magill, A., Berntson, G., Kamakea, M., McNulty, S., Currie, W., Rustad, L. and Fernandez, I.: 1998, 'Nitrogen saturation in temperate forest ecosystems - Hypotheses revisited', BioScience 348, 921-934.

Ågren, G.I. and Bosatta, E.: 1988, 'Nitrogen saturation of terrestrial ecosystems', Environ. Pollut. 54, 185-197.

Creed, I. F. and Band, L. E.: 1998, 'Export of nitrogen from catchments within a temperate forest: evidence for a unifying mechanism regulated by variable source area dynamics', Water Resour. Res. 34, 3105-3120.

Davidson, E. A., Chorover, J. and Dail, D. B.: 2003, 'A mechanism of abiotic immobilization of nitrate in forest ecosystems: the ferrous wheel hypothesis', Global Change Biol. 9, 228-236.

Downs, M. R., Michener, R. H., Fry, B. and Nadelhoffer, K. J.: 1999, 'Routine measurement of dissolved inorganic ${ }^{15} \mathrm{~N}$ in streamwater', Environ. Monit. Assess. 55, 211-220.

Emmett, B. A., Boxman, A. W., Bredemeier, M., Moldan, F., Gundersen, P., Kjønaas, O. J., Schleppi, P., Tietema, A. and Wright, R. F.: 1998, 'Predicting the effects of atmospheric nitrogen deposition in conifer stands: evidence from the NITREX ecosystem-scale experiments', Ecosystems 1, 352360.

Feyen, H., Wunderli, H., Wydler, H. and Papritz, A.: 1999, 'A tracer experiment to study flow paths of water in a forest soil', J. Hydrol. 225, 155-167.

Gundersen, P., Emmett, B. A., Kjønaas, O. J., Koopmans, C. J. and Tietema, A.: 1998, 'Impact of nitrogen deposition on nitrogen cycling in forests: a synthesis of NITREX data', For. Ecol. Manage. 101, 37-55.

Hagedorn, F., Mohn, J., Schleppi, P. and Flühler, H.: 1999, 'The role of rapid flow paths for nitrogen transformation in a forest soil: a field study with micro suction cups', Soil Sci. Soc. Am. J. 63, 1915-1923.

Hagedorn, F., Schleppi, P., Waldner, P. and Flühler, H.: 2000, 'Export of dissolved organic carbon and nitrogen from Gleysol dominated catchments - the significance of water flow paths', Biogeochemistry 50, 137-161.

Hagedorn, F., Schleppi, P., Bucher, J. B. and Flühler, H.: 2001, 'Retention and leaching of elevated $\mathrm{N}$ deposition in a forested ecosystem with Gleysols', Water, Air, Soil Pollut. 129, 119-142.

Johnson, D. W.: 1992, 'Nitrogen retention in forest soils', J. Environ. Qual. 21, 1-12.

Mayer, B., Boyer, E. W., Goodale, C., Jaworski, N. A., van Breemen, N., Howarth, R. W., Seitzinger, S., Billen, G., Lajtha, K., Nadelhoffer, K., van Dam, D., Hetling, L. J., Nosal, M. and Paustian, K.: 2002, 'Sources of nitrate in rivers draining sixteen watersheds in the northeastern U.S.: isotopic constraints', Biogeochemistry 57-58, 171-197.

Persson, H.: 1981, 'The effect of fertilization and irrigation on the vegetation dynamics of a pineheath ecosystem', Vegetatio 46, 181-192.

Schleppi, P., Muller, N., Feyen, H., Papritz, A., Bucher, J. B. and Flühler, H.: 1998, 'Nitrogen budgets of two small experimental forested catchments at Alptal, Switzerland', For. Ecol. Manage. 101, $177-185$. 
Schleppi, P., Bucher-Wallin, I., Siegwolf, R., Saurer, M., Muller, N. and Bucher, J. B.: 1999a, 'Simulation of increased nitrogen deposition to a montane forest ecosystem: partitioning of the added ${ }^{15}$ N', Water, Air, Soil Pollut. 116, 129-134.

Schleppi, P., Muller, N., Edwards, P. J. and Bucher, J. B.: 1999b, 'Three years of increased nitrogen deposition do not affect the vegetation of a montane forest ecosystem', Phyton 39, 199-204.

Stoddard, J. L.: 1994, 'Long-term changes in watershed retention of nitrogen: its causes and aquatic consequences', in L. A. Baker (ed.), Environmental Chemistry of Lakes and Reservoirs, Adv. Chem. Ser. 237, Am. Chem. Soc., Washington, DC, U.S.A., pp. 223-284.

Waldner, P., Schneebeli, M. and Wunderli, H.: 2000, 'Nährstoffaustrag aus einer schmelzenden Schneedecke im Alptal (Kanton Schwyz) am Beispiel von Nitrat', Schweiz. Z. Forstwes. 151, 198-204.

Wilson, E. J. and Tiley, C.: 1998, 'Foliar uptake of wet-deposited nitrogen by Norway spruce: an experiment using ${ }^{15} \mathrm{~N}$ ', Atmos. Environ. 32, 513-518.

Wright, R. F. and Rasmussen, L.: 1998, 'Introduction to the NITREX and EXMAN projects', For. Ecol. Manage. 101, 1-7. 